Section Editor

Mitchell S.V. Elkind,

MD, MS

Amar Dhand, MD, DPhil

Correspondence \& reprint requests to Dr. Dhand:

amar.dhand@ucsf.edu

Right Brain:

\title{
The case library as a tool to enhance clinical observation
}

For many years he had adopted a system of docketing all paragraphs concerning men and things, so that it was difficult to name a subject or a person on which he could not at once furnish information.

—Watson describing Sherlock Holmes' index ${ }^{1}$

A case library is a collection of patients' details organized systematically and analyzed comparatively. Analogous to browsing titles on a library shelf, it inspires the user to scan within and across cases to elicit deeper insights than from reviewing any individual one. The analysis, whether qualitative or quantitative, is based fundamentally on the general method of comparative analysis - evaluation of similarities and differences to create embedded categories leading to hypotheses and generalizable theories. ${ }^{2} \mathrm{~A}$ case library is distinct from a case $\log$ in its emphasis on discovery and analysis often simultaneously with data collection; it is not a list of cases accumulated and then scrutinized, but rather an evolving catalog in which every new entry is related to prior entries and regrouped accordingly.

Historically, collecting and analyzing cases comparatively have yielded unique clinical observations. Early hypotheses of mechanism and nosology were analyses of similar cases presented in case series format. ${ }^{3}$ C. Miller Fisher was a quintessential utilizer of this method. In the following passage, he describes how his comparative analysis sensitized him to make an important observation:

My interest was attracted to this subject when within the same week two patients reported transient blindness in one eye as a prodrome of the development of severe hemiplegia. As more attention was paid to patients' complaints about their vision, other cases were encountered, and this paper is a report of seven. ${ }^{4}$

Similarly, Rajput and colleagues maintained a 39year database in which they compared 3 clinicopathologic subtypes of Parkinson disease to reveal divergent natural histories. ${ }^{5}$

At the beginning of my neurology residency, I decided to create and maintain a case library. Initially, this had a practical purpose: to follow-up on patients after a month-long rotation. The Excel doc- ument included details on all unique inpatients and outpatients for whom I was the initial evaluator and wrote a new patient note. Data included demographics, chief complaint, diagnosis, treatment, and sociocultural details. Using this system, I kept up with final test results and subsequent clinic notes to gauge my diagnostic and therapeutic success. I studied my errors and reflected on their cognitive and social components. For example, a patient with foot numbness and instability who I diagnosed with diabetic neuropathy was found to have anti-myelin-associated glycoprotein neuropathy, a diagnosis I may have considered more strongly if I had attended to her preferential sensory ataxia. Therefore, the initial utility of the library was feedback; it was a structure to review my clinical practice one case at a time.

As the cases accumulated, however, it became apparent that the value of the library went beyond feedback on individual cases. I began to look at chunks of cases and asked questions about their underlying relations. For example, I studied why my patients with cervical myelopathy presented with a polymorphic symptomology. This guided my reading and conversations with experts. In the medical education literature, this strategy is called "deep learning"-a relational approach to understanding material by seeking patterns in personal experience, previous knowledge, and real world phenomena. ${ }^{6}$ In contrast to nonrelational, memorization-based surface learning, deep learning is shown to correlate with increased performance on standardized assessments. ${ }^{\text {? }}$ The iterative reengagement of topics over time, known as the spacing effect, has also shown positive effects on long-term retention of material. ${ }^{8}$

Category creation followed as a natural continuation of the deep learning approach. To organize my clinical experience over 15 months, I created and recreated categories from case to case comparisons and literature consultation. Specifically, I sorted the Excel sheet by disease category, examined the relation of the cases to each other, and iteratively refined the category structure to represent the data. In this way, 
there was an evolution of labels as certain cases were grouped together ("Cognitive disorders-autoimmune limbic encephalitis") and differentiated from other cases ("Infectious diseases-encephalitis"). When I entered a new case, the process was reinitiated as categories were challenged and changed, or became fortified with another clear example. The evolving category structure was dependent on my increasing clinical experience; as I saw more variants the categories became richer and more robust.

In the end, the importance of the case library lay in its influence on my clinical perception and future generation of theories. As I wrote this piece, I encountered my second case of cryptococcal meningitis vs immune reconstitution inflammatory syndrome in a patient with HIV. I reviewed my first patient's entry nearly 2 years ago, comparing and contrasting features. I read the scant literature such as one case series of 3 patients. ${ }^{9}$ At the bedside of my new patient, my clinical vision was enhanced as I asked pointed questions about seizures and the initiation of antiretroviral therapy, critical issues for the last patient. I entered the details of the new patient in my case library and considered reorganizing cases under a new category of "HIV neurology."

The case library is, thus, a living document changing with every new case, provoking learning, honing clinical perception, and building new ideas. Residency, as a time when the caseload is never more diverse, is the ideal moment to apply this method and see things that may be left unnoticed. Such is a lesson from history that may be the key to learning and making new discoveries.

\section{ACKNOWLEDGMENT}

The author thanks Dr. Gurpreet Dhaliwal for his ideas to sharpen this piece.

\section{DISCLOSURE}

Dr. Dhand is the resident member of the ACGME Neurology Resident Review Committee.

\section{REFERENCES}

1. Doyle AC. A scandal in bohemia. In: Doyle AC. The Adventures of Sherlock Holmes. New York: Berkley Publishing; 1891:7-31.

2. Glaser BG, Strauss AL. The Discovery of Grounded Theory: Strategies for Qualitative Research. New York: Alpine de Gruyter; 1999.

3. Charcot J, Richer P. On a muscular phenomenon observed in hysteria, and analogous to the "paradoxical contraction." Brain 1885;8:289-294.

4. Fisher CM. Transient monocular blindness associated with hemiplegia. Arch Ophthalmol 1952;47:167-203.

5. Rajput AH, Voll A, Rajput ML, Robinson CA, Rajput A. Course in Parkinson disease subtypes: a 39-year clinicopathologic study. Neurology 2009;73:206-212.

6. Marton F, Salijo R. The Experience of Learning. Edinburgh: Scottish Academic Press; 1985.

7. Newble DI, Entwistle NJ. Learning styles and approaches: implications for medical education. Med Educ 1986;20: 162-175.

8. Bahrick HP, Hall LK. The importance of retrieval failures to long-term retention: A metacognitive explanation of the spacing effect. J Memory Lang 2005;52:566-577.

9. Venkataramana A, Pardo CA, McArthur JC, et al. Immune reconstitution inflammatory syndrome in the CNS of HIV-infected patients. Neurology 2006;67:383-388. 


\section{Neurology}

\section{Right Brain: The case library as a tool to enhance clinical observation \\ Amar Dhand \\ Neurology 2012;78;512-513 \\ DOI 10.1212/WNL.0b013e318246d6c8}

This information is current as of February 13, 2012

Updated Information \&

Services

References

Subspecialty Collections

Permissions \& Licensing

Reprints including high resolution figures, can be found at:

http://n.neurology.org/content/78/7/512.full

This article cites 6 articles, 2 of which you can access for free at: http://n.neurology.org/content/78/7/512.full\#ref-list-1

This article, along with others on similar topics, appears in the following collection(s):

Clinical neurology history

http://n.neurology.org/cgi/collection/clinical_neurology_history

CME

http://n.neurology.org/cgi/collection/cme

Error in medicine

http://n.neurology.org/cgi/collection/error_in_medicine

Methods of education

http://n.neurology.org/cgi/collection/methods_of_education

Information about reproducing this article in parts (figures,tables) or in its entirety can be found online at:

http://www.neurology.org/about/about_the_journal\#permissions

Information about ordering reprints can be found online:

http://n.neurology.org/subscribers/advertise

Neurology ${ }^{\circledR}$ is the official journal of the American Academy of Neurology. Published continuously since 1951, it is now a weekly with 48 issues per year. Copyright Copyright (? 2012 by AAN Enterprises, Inc.. All rights reserved. Print ISSN: 0028-3878. Online ISSN: 1526-632X.

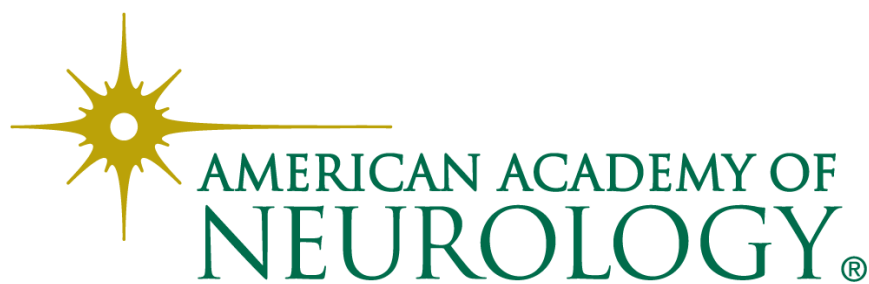

